\title{
Phytoplankton response to high salinity and nutrient limitation in the eastern Adriatic marine lakes
}

\author{
MARINA CARIĆ, NENAD JASPRICA, MARIJETA ČALIĆ and MIRNA BATISTIĆ \\ Institute for Marine and Coastal Research, University of Dubrovnik, P.O. Box 83, HR-20000 Dubrovnik, Croatia. \\ E-mail: marina.caric-gluncic@unidu.hr
}

SUMMARY: Phytoplankton and physical-chemical parameters were investigated for the first time in the only natural hyperhaline marine lakes (salinity $>40$ ) along Croatia's Adriatic coast, Mala Solina and Velika Solina. Two periods were recognized during the one-year investigation: one euhaline-mesotrophic from December to May and one hyperhalineeutrophic from June to November. Nutrient limitation appears to have been important in defining the lakes' seasonal phytoplankton composition. Phosphate was most likely limiting from October to December, silicate from January to April, and nitrogen from June to September when nitrate was depleted. Diatoms were most abundant in November to January, when temperature and salinity were low and nitrate and ammonium were high. They collapsed in March when silicate was depleted. Amphora, Navicula, and other naviculoid diatoms were the most frequent genera. Nitzschia longissima was the most abundant species. Dinoflagellate dominance began in June in Mala Solina and in March in Velika Solina. It continued while temperature, salinity, phosphate, and silicate were high. Oxyrrhis marina was the most abundant dinoflagellate $\left(3.2 \times 10^{6}\right.$ cells $\left.\mathrm{L}^{-1}\right)$. Nanophytoplankton was the dominant size fraction. Chroococoid cyanobacteria were most abundant from May to October, reaching $2.9 \times 10^{7}$ cells L ${ }^{-1}$ in July. Both nanophytoplankton and small microphytoplankton, such as Oxyrrhis, Scrippsiella, and Tetraselmis, were most abundant under hyperhaline, N-depleted conditions. Toxic and harmful taxa (e.g. Alexandrium, Dinophysis), expanding in Mediterranean waters, were not recorded in the lakes.

Keywords: phytoplankton, hydrography, nutrients, eutrophication, marine lakes, Adriatic Sea.

RESUMEN: RESPUESTA DEL FITOPLANCTON A LA LIMITACIÓN DE NUTRIENTES Y SALINIDAD ELEVADA EN LAGUNAS HIPERSALINAS EN EL ADRIÁTICO ORIENTAL. - El fitoplancton y diversos parámetros físico-químicos fueron estudiados por primera vez en dos lagunas hiperhalinas naturales (salinidad >40) de la costa de Croacia, Mala Solina y Velika Solina. El estudio se llevó a cabo durante 1 año, y pudieron distinguirse dos períodos: uno euhalino - mesotrófico, de diciembre a mayo, y el otro hiperhalino - eutrófico, de junio a noviembre. La limitación por nutrientes resultó ser un factor determinante para las variaciones estacionales en la composición del fitoplancton de las lagunas. El fosfato fue limitante de octubre a diciembre, el silicato de enero a abril, y el nitrógeno de junio a septiembre, una vez consumido el nitrato. Las diatomeas fueron especialmente abundantes entre noviembre y enero, cuando la temperatura y la salinidad eran bajas y la concentración de nitrato y amonio eran altas. El número de diatomeas disminuyó en marzo, tras el agotamiento del silicato. Amphora, Navicula y otras diatomeas naviculares fueron el género más frecuente, y Nitzschia longissima fue la especie más abundante. La dominancia de dinoflagelados comenzó en junio en Mala Solina y en marzo en Velika Solina, y se mantuvo mientras la temperatura, la salinidad, y las concentraciones de fosfato y silicato fueron altas. Oxyrrhis marina fue el dinoflagelado más abundante $\left(3.2 \times 10^{6}\right.$ células $\left.\mathrm{L}^{-1}\right)$. El nanofitopláncton fue la fracción de tamaño dominante en la comunidad. Las cianobacterias Chroococcales fueron muy abundantes de mayo a octubre, alcanzando concentraciones de $2.9 \times 10^{7}$ células $\mathrm{L}^{-1}$ en julio. El nanofitoplancton y el microfitoplancton más pequeño, como Oxyrrhis, Scrippsiella, o Tetraselmis, fueron particularmente abundantes en condiciones hiperhalinas y pobres en nitrógeno. Taxones tóxicos y nocivos (por ejemplo Alexandrium, Dinophysis), expandiéndose en las aguas del Mediterráneo, no han sido detectados en los lagos.

Palabras clave: fitoplancton, hidrografía, nutrientes, eutrofización, lagunas costeras, mar Adriático. 


\section{INTRODUCTION}

Wide seasonal variation of physical and chemical parameters in temperate coastal ecosystems influences biological processes (e.g. growth and grazing rates) that affect phytoplankton abundance (Smayda, 1980; Reynolds, 1997; Longhurst, 1998). Pelagic production in these systems is stimulated by nutrient inputs from the watershed (Kemp and Boynton, 1984) and coupled to benthic production (Johnson and Wiederholm, 1992; Miller-Way and Twilley, 1996). Regardless of their proximate source, nutrients that support phytoplankton growth may be characterized broadly in terms of the atomic ratios of inorganic nitrogen, phosphorus and, in the case of diatoms, silicon (N:P:Si) (Redfield et al., 1963; Brzezinski, 1985). Changes in nutrient supply are often reflected in their ratios (Yin et al., 2001). Significant deviations from the typical ratio may signal nutrient-limitation (Dorth and Whitledge, 1992).

Small, well-defined natural systems, such as the marine lakes of Croatia's Adriatic coast, offer an opportunity to study nutrient-phytoplankton interactions without many of the complications encountered in the open ocean and on a much larger scale than is practical in the laboratory. Furthermore, because the Croatian lakes span a range of hydrographic and trophic conditions, the response of phytoplankton assemblages to considerably different nutrient environments may be compared. According to the Venice System (Anonymous, 1959), most of the marine lakes in question are euhaline (salinity 30-40) and slightly or only moderately eutrophic (Jasprica et al., 1995; Carić and Jasprica, 2005; Čalić et al., 2007). They typically support higher biomass but lower diversity than is found in adjacent Adriatic coastal waters (Kršinić et al., 2000). In particular, phytoplankton diversity is generally lower and diatoms are the dominant group. Plankton studies in these lakes have started only recently ( $c f$. Jasprica and Carić, 2001) and much remains to be investigated. These lakes include two hyperhaline (salinity >40) lakes on the central Adriatic coast, Mala ("Little") Solina and Velika ("Big") Solina (Fig. 1).

Phytoplankton studies in Mediterranean hyperhaline environments are relatively scarce, but it is clear that salinity generally determines the distribution of taxa and that other factors - such as predation, competition, nutrients and prey availability-play a major role in controlling seasonal patterns (Elloumi et al., 2009). One such study in two Tunisian lagoons of very different salinities (40 and 90), in which diatoms and dinoflagellates predominated, observed lower abundance, species richness and diversity at higher salinity (Ayadi et al., 2004). The present work contributes to the understanding of phytoplankton cycles in hyperhaline environments of the Mediterranean coast by reporting the first data on phytoplankton composition and seasonal distribution in two hyperhaline Adriatic ecosystems. Particular attention has been paid to interpreting the importance of key environmental variables,

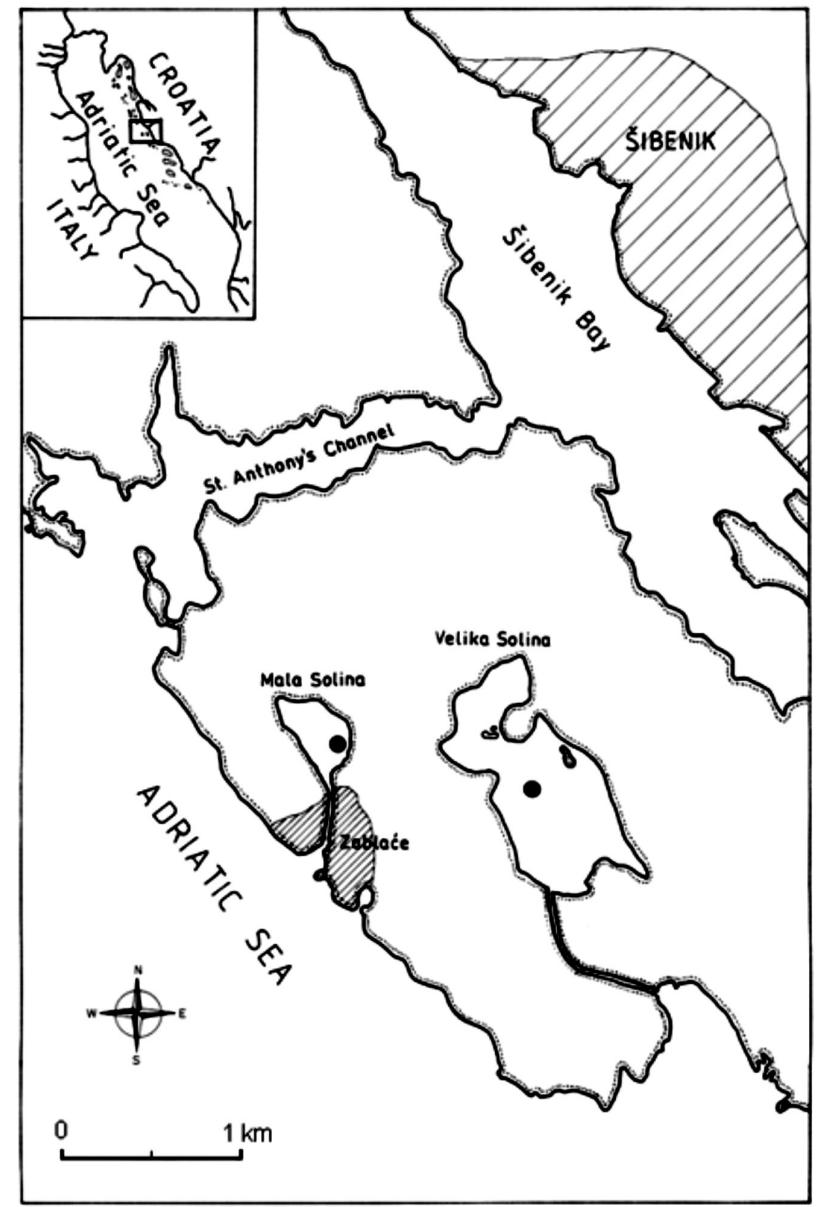

FIG. 1. - Geographic location of Mala Solina and Velika Solina with sampling sites.

particularly nutrient ratios, as predictors of phytoplankton abundance and structure.

\section{Study area}

Mala Solina (4342'43.54'N, $15^{\circ} 52^{\prime} 0.89^{\prime}$ 'E) and Velika Solina $\left(43^{\circ} 42^{\prime} 31.71^{\prime \prime} N, 15^{\circ} 52^{\prime} 59.99^{\prime \prime}\right.$ ) $)$ are hyperhaline marine lakes located along the Republic of Croatia's central Adriatic coast. The region has a typical Mediterranean climate of warm, dry summers and mild, rainy winters (Blondel and Aronson 1999). Average annual air temperature is $15.3^{\circ} \mathrm{C}$ and precipitation averages $789.8 \mathrm{~mm} \mathrm{yr}^{-1}$ (data from the nearby Šibenik station for 1961-2000, Croatian Meteorological and Hydrological Service). The lakes are about 9 kilometres from the town of Sibenik (37060 in 2001) and near the village of Zablaće (Fig. 1). Zablaće, situated around Mala Solina, has 500 year-round inhabitants, but this number increases several-fold in summer. Mala Solina is thus exposed to a seasonal pattern of anthropogenic influence, especially discharge of untreated domestic waste.

Both lakes are very shallow, with a maximum depth of $1 \mathrm{~m}$ in Mala Solina and $1.5 \mathrm{~m}$ in Velika Solina. Mala Solina has a surface area of 15 ha and 
a volume of $60000 \mathrm{~m}^{3}$; Velika Solina has a surface area of 90 ha and a volume of $810000 \mathrm{~m}^{3}$. The bottoms of both are partly covered with dense meadows of Cymodocea nodosa. Salt-marsh vegetation of the Sarcocornetea fruticosi vegetation class is distributed around each. These low, marshy coasts are a rare habitat of ecological value and are listed in Annexes of the EU Directive on the Conservation of natural habitats and of wild fauna and flora (Council Directive 92/43/EEC, 1992). Each lake has a narrow channel that connects it to the Adriatic, whose average sea level is $59.1 \mathrm{~cm}(1955-2004)$ at the nearest coastal station (Domijan, 2006). The channel that links Mala Solina to the sea is $200 \mathrm{~m}$ long and 1-2 m wide, and has a maximum depth of $30 \mathrm{~cm}$; the one that links Velika Solina to the sea is $1 \mathrm{~km}$ long and 2-4 $\mathrm{m}$ wide, and has a maximum depth of $2 \mathrm{~m}$. Projects are underway as of this writing to enlarge these channels to increase water exchange that, along with seasonal wind patterns, drives circulation in the lakes. North winds generally dominate from January to March, in June, and again from August to October; southwest winds prevail the rest of the year (Meteorological and Hydrological Service of Croatia).

\section{MATERIALS AND METHODS}

\section{Sampling and laboratory procedures}

Physical-chemical parameters and phytoplankton were collected monthly from November 1999 to October 2000, except for February 2000. The sampling station was situated at the deepest part of each lake: 10 $\mathrm{m}$ from shore for Mala Solina and $20 \mathrm{~m}$ from shore for Velika Solina. Samples were taken at mid-day with a 5 -L Niskin bottle at $0.5 \mathrm{~m}$, a depth midway between the surface and bottom. Transparency was measured with a 30-cm diameter Secchi disc. Temperature, salinity, density (expressed as sigma-t), dissolved oxygen, and nutrients (nitrate $\mathrm{NO}_{3}$, nitrite $\mathrm{NO}_{2}$, ammonium $\mathrm{NH}_{4}$, phosphate $\mathrm{PO}_{4}$, and silicate $\mathrm{SiO}_{4}$, ) were determined by standard oceanographic methods (Strickland and Parsons, 1972). Oxygen saturation $\left(\mathrm{O}_{2} / \mathrm{O}_{2}^{\prime}\right)$ was calculated from the solubility of oxygen in seawater as a function of temperature and salinity (Weiss, 1970; UNESCO, 1973).

Trophic status was characterized by the TRIX index, commonly used to classify coastal marine areas in the Mediterranean (Vollenweider et al., 1998, Karydis, 2009):

$$
\text { TRIX }=(\log [C h A \times D \% O \times D I N \times T P]+k) / m
$$

Each of the four factors in the argument of the logarithm represents a variable understood to reflect trophic state: $C h A=$ chlorophyll $a$ concentration $[\mu \mathrm{g}$ $\mathrm{L}^{-1}$ ], $D \% O=$ dissolved oxygen [absolute $\%$ deviation from saturation], dissolved inorganic nitrogen DIN = $\left(\mathrm{NO}_{3}+\mathrm{NO}_{2}+\mathrm{NH}_{4}\right)\left[\mu \mathrm{g} \mathrm{L}^{-1}\right]$, and $\mathrm{TP}=$ total phosphorus
[ $\mu \mathrm{g} \mathrm{L}^{-1}$ ]. The parameters $k=1.5$ and $m=1.2$ set the range of the TRIX scale from 0 to 10 (0-4 oligotrophic, 4-5 mesotrophic, 5-6 eutrophic, 6-10 extremely eutrophic).

Chlorophyll $a(\mathrm{Chl} a)$ was determined from 500$\mathrm{mL}$ sub-samples filtered through Whatman GF/F glassfibre filters stored at $-20^{\circ} \mathrm{C}$. These were homogenized and extracted in $90 \%$ acetone for $24 \mathrm{~h}$ at room temperature (Holm-Hansen et al., 1965). Samples were analyzed fluorometrically with a Turner TD-700 Laboratory Fluorometer (Sunnyvale, CA) calibrated with pure Chl $a$ (Sigma).

Phytoplankton samples were preserved in neutralized formalin (2\% final concentration) and viewed with an Olympus IX-71 inverted microscope equipped with bright-field and phase contrasts (Utermöhl, 1958). Sub-samples $(50 \mathrm{~mL})$ were settled for 24 hours in counting chambers before analysis. Counts of microphytoplankton (MICRO >20 $\mu \mathrm{m}$,) were done at $200 \times$ in 2-4 transects made across the central part of the counting chamber base plate and at $100 \times$ on the remainder of the chamber base plate. This fraction was divided into five groups: BACI (Heterokontophyta, Bacillariophyceae), diatoms; DINO (Dinophyta, Dinophyceae), dinoflagellates; PRYM (Prymnesiophyta, Prymnesiophyceae), coccolithophorids; CHLO (Chlorophyta, Prasinophyceae), green algae; and OTHER phytoplankton (filamentous cyanobacteria, Euglenophyceae and unidentified spherical cells). Whenever possible, identification was taken to the species or genus level using standard taxonomic guides (Kofoid and Swezy, 1921; Hustedt, 1930; Schiller, 1933, 1937; Cupp, 1943; Sournia, 1986; Tomas, 1993, 1996; Bérard-Therriault et al., 1999; Horner, 2002). The nomenclature of higher taxa (phyla, classes) follows Lee (1999). Nanophytoplankton (NANO, cells 2-20 $\mu \mathrm{m}$ ) was counted in 30 randomly selected fields-of-view at $400 \times$.

\section{Species richness and similarity indices}

Microphytoplankton species associations between the lakes were compared with Jaccard's similarity index (Jaccard, 1908), which is based on the presence/ absence of a species rather than on its actual numbers:

$$
\mathrm{JI}=100[\mathrm{a} /(\mathrm{a}+\mathrm{b}+\mathrm{c})]
$$

where $a$ is the number of species present in both lakes; $b$ is the number in lake 1 but not lake 2 ; and $c$ is the number in lake 2 but not lake 1 . Double absences were not considered.

Margalef's index (Margalef, 1965) was used to characterize species richness:

$$
D=S-1 / \log N
$$

where $S$ is the number of species and $N$ the number of individuals counted to obtain $S$ species. 


\section{Statistical analyses}

Pearson product-moment correlations were calculated between physical-chemical parameters and phytoplankton species abundance. Ordination was performed using non-metric multidimensional scaling (MDS) based on the Bray-Curtis similarity matrix (Clarke and Warwick, 2001). MDS was applied to define the similarity of sampling dates with the respect to phytoplankton composition. ANOSIM randomization was used to test for significant differences in phytoplankton community structure. The dissimilarity percentage program (SIMPER) was used to identify the

Temperature
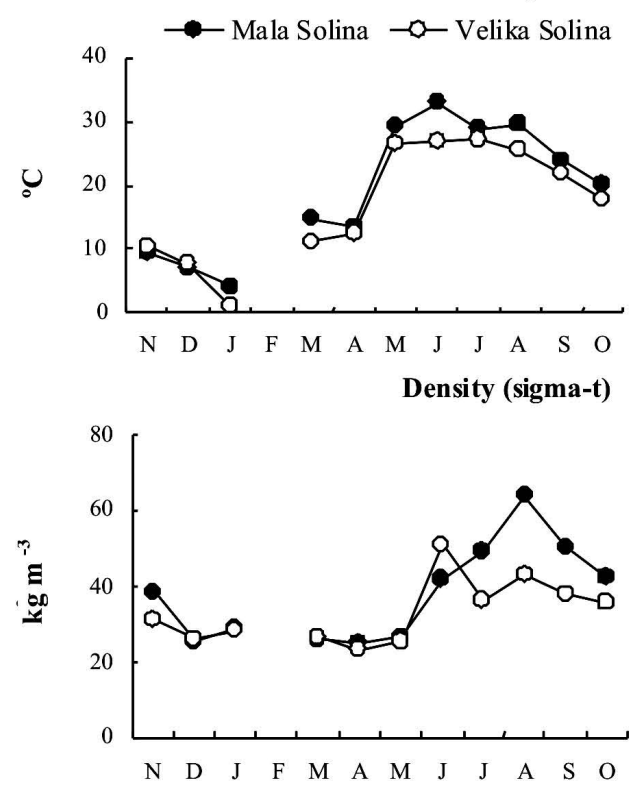

$\mathrm{NH}_{4}$

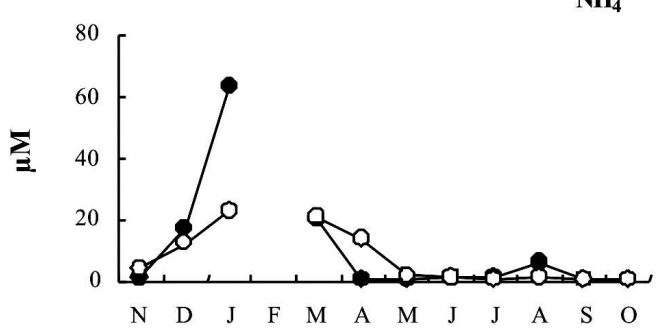

$\mathrm{PO}_{4}$

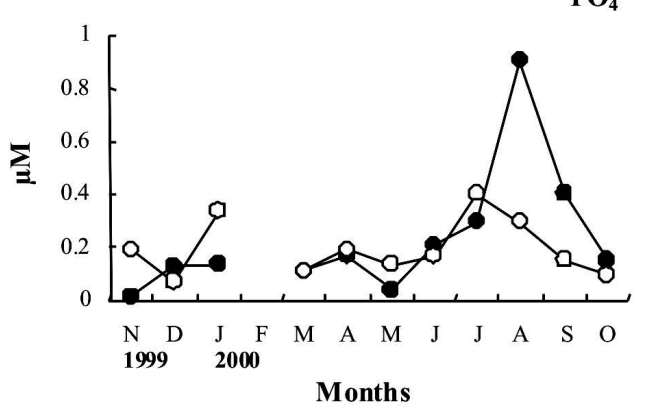

FIG. 2. - Monthly distribution of physical-chemical parameters in Mala Solina and Velika Solina.
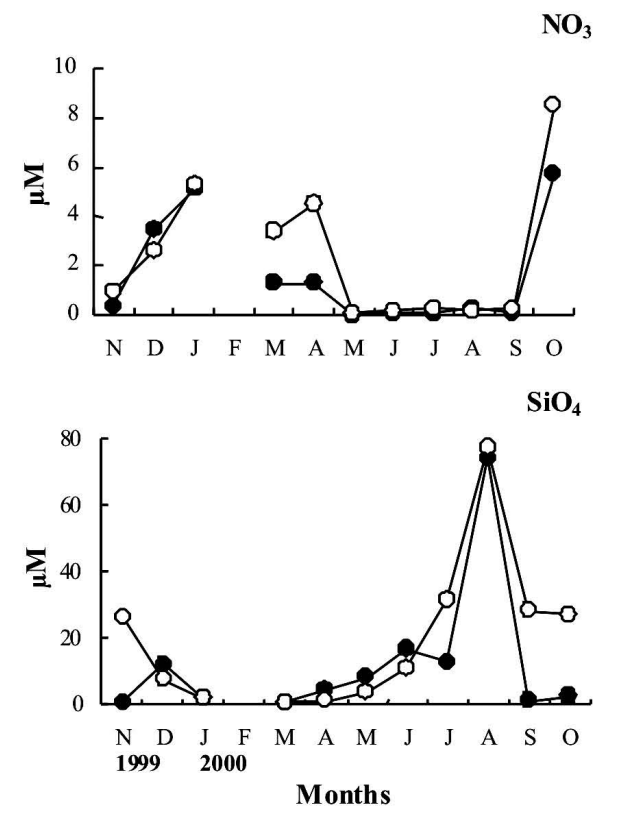

species making the greatest contribution to differences between clusters observed in the MDS plot. Statistical analyses were performed with STATISTICA (StatSoft Inc., Tulsa, OK) and PRIMER v5 software (Clarke and Gorley, 2001).

\section{RESULTS}

\section{Environmental conditions}

Secchi disc transparency ceased down to the bottom of lakes throughout the year. Water temperature (Fig. 2) ranged from $3.9^{\circ} \mathrm{C}$ (January) to $33^{\circ} \mathrm{C}$ (June) in Mala
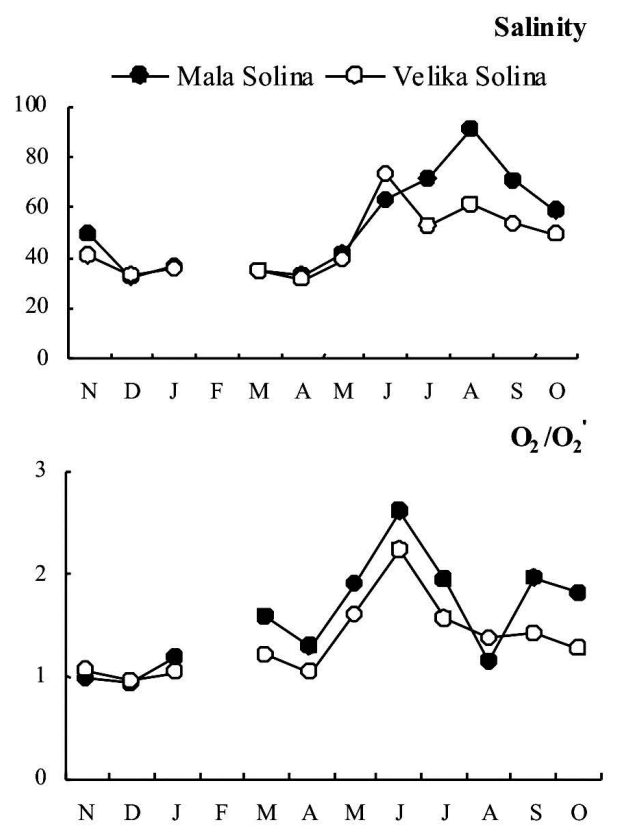

$\mathrm{NO}_{3}$

$\mathrm{SiO}_{4}$ 


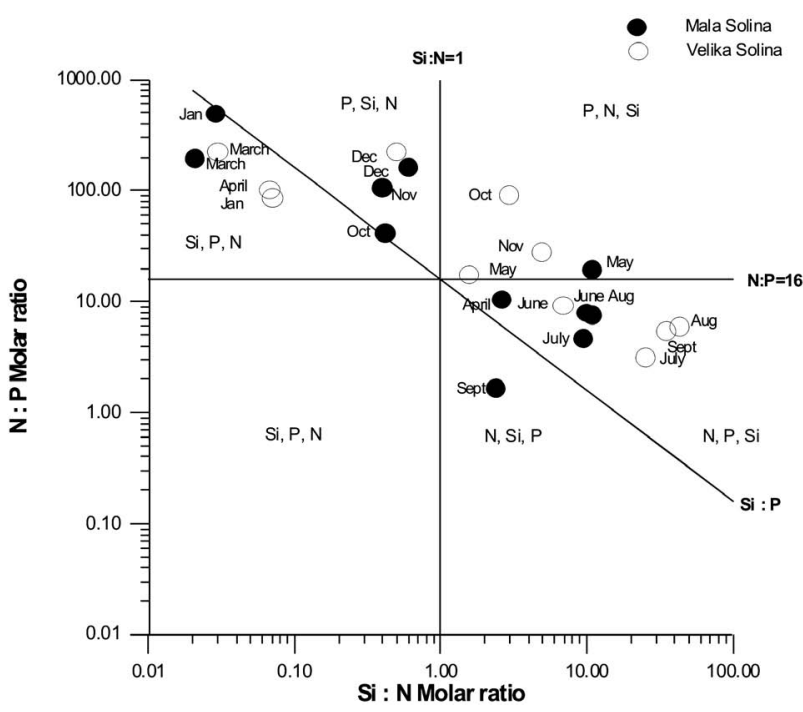

FIG. 3. - Si:N:P $\left[\mathrm{SiO}_{4}:\left(\mathrm{NO}_{3}+\mathrm{NO}_{2}+\mathrm{NH}_{4}\right): \mathrm{PO}_{4}\right]$ molar ratios in Mala Solina and Velika Solina. Molar quotients between in situ concentrations of potentially limiting nutrients are delimited by Si:N $=1, \mathrm{~N}: \mathrm{P}=16$, and $\mathrm{Si}: \mathrm{P}=16$ lines. Lines define six different areas within the plot, each characterized by a potentially limiting nutrient in order of priority (Rocha et al., 2002).

Solina and from $0.9^{\circ} \mathrm{C}$ (January) to $27.3^{\circ} \mathrm{C}$ (July) in Velika Solina. In both lakes it rose steadily from March to May, remained fairly constant in August, and began to decrease in September. Salinity (Fig. 2) varied from 32.5 (December) to 90.5 (August) in Mala Solina; it was lower in Velika Solina, varying from 30.9 (April) to 72.55 (June). It increased in both lakes starting in May and was high from June to October. Seasonal density changes tracked salinity, ranging from 25.1 to 64.1 $\mathrm{kg} \mathrm{m}^{-3}$ in Mala Solina and 23.4 to $51.2 \mathrm{~kg} \mathrm{~m}^{-3}$ in Velika Solina. Dissolved oxygen ranged from 3.69 to $9.28 \mathrm{ml}$ $\mathrm{L}^{-1}$ and from 5.54 to $8.24 \mathrm{ml} \mathrm{L}^{-1}$ and with saturation $\left(\mathrm{O}_{2} / \mathrm{O}_{2}{ }^{\prime}\right)$ it ranged from 0.93 to 2.6 and 0.96 to 2.23 , respectively, in Mala and Velika Solina.

Nitrate ranged from 0.03 (May) to 5.70 (October) $\mu \mathrm{M}$ in Mala Solina and from 0.08 (May) to 8.53 (October) $\mu \mathrm{M}$ in Velika Solina. Higher values were found from December to April. Ammonium varied from 0.46 (April) to 63.49 (January) $\mu \mathrm{M}$ in Mala Solina and from 0.52 (September) to 23.23 (January) $\mu \mathrm{M}$ in Velika Solina. Ammonium was very high from December to April, with Mala Solina exhibiting a particularly high value $(6.53 \mu \mathrm{M})$ in August. Phosphate $\left(\mathrm{PO}_{4}\right)$ ranged from 0.02 (November) to 0.9 (August) $\mu \mathrm{M}$ in Mala Solina and from 0.07 (December) to 0.4 (July) $\mu \mathrm{M}$ in Velika Solina. Mala Solina's values were high from July to September. Silicate $\left(\mathrm{SiO}_{4}\right)$ ranged from 0.44 (March) to 74.01 (August) $\mu \mathrm{M}$ in Mala Solina and from 0.73 (March) to 77.41 (August) $\mu \mathrm{M}$ in Velika Solina. High values of around $30 \mu \mathrm{M}$, however, were found only in Velika Solina and in November, July, September, and October. Molar quotients of potentially limiting nutrients are shown in Figure 3. $\mathrm{PO}_{4}$ was most likely limiting from October to December, $\mathrm{SiO}_{4}$ from

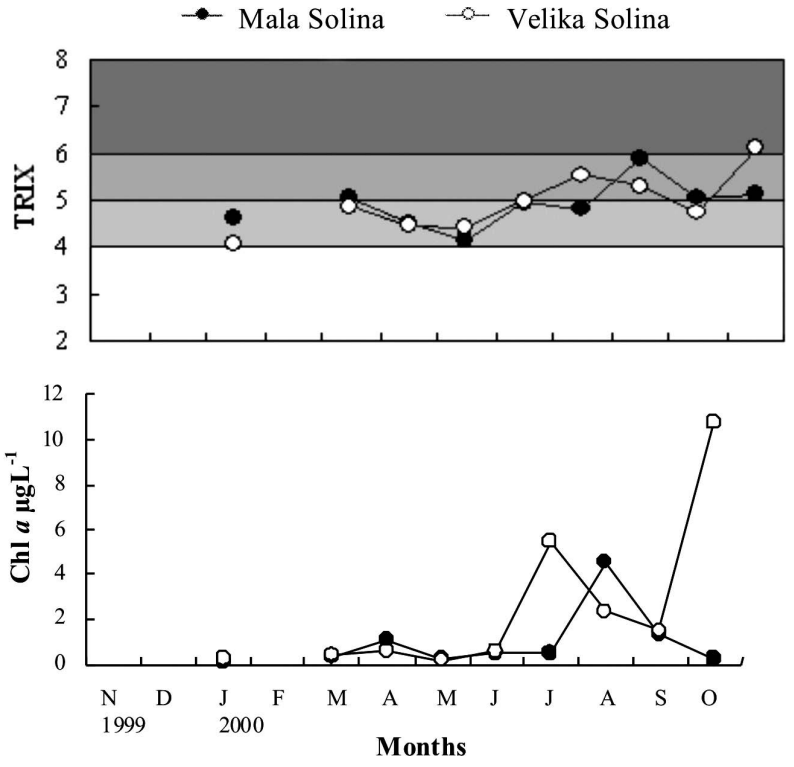

FIG. 4. - Chlorophyll $a$ concentration (Chl $a$ ) and TRIX units (0-4 oligotrophic, 4-5 mesotrophic, 5-6 eutrophic, 6-10 extremely eutrophic) in Mala Solina and Velika Solina during the 1-year investigation.

January to April, and $\mathrm{N}$ from June to September, a period of $\mathrm{NO}_{3}$ depletion. Trophic status was 4-5 TRIX units until May and 5-6 from June to October (Fig. 4). Chl $a$ ranged from 0.08 (January) to $4.51 \mu \mathrm{g} \mathrm{L}^{-1}$ (August) in Mala Solina and from 0.08 (January) to 10.71 $\mu \mathrm{g} \mathrm{L}^{-1}$ (October) in Velika Solina (Fig. 4).

\section{Phytoplankton}

Microphytoplankton (MICRO) varied from $1.3 \mathrm{x}$ $10^{3}$ to $5.1 \times 10^{6}$ cells $\mathrm{L}^{-1}$ in Mala Solina and from $1.2 \mathrm{x}$ $10^{3}$ to $2.6 \times 10^{5}$ cells L ${ }^{-1}$ in Velika Solina (Fig. 5). The highest abundances were in summer: August in Mala Solina and July in Velika Solina. The lowest were in January in Mala Solina and March in Velika Solina. Monthly variations of MICRO and their percentage of total abundance (Fig. 6) show that dinoflagellates were the most abundant group and largely responsible for the MICRO peak. Dinoflagellates dominated MICRO in November and again from June to October in Mala Solina (76.8-99.5\%). In Velika Solina, dinoflagellates dominated from March to October (77.5-98.5\%), with the exception of June. Maximum diatom abundance in Mala Solina $\left(1.17 \times 10^{6}\right.$ cells L ${ }^{-1}$, August $)$ occurred two months later and was about two orders of magnitude higher than in Velika Solina $\left(3.49 \times 10^{4}\right.$ cells $\mathrm{L}^{-1}$, June). Diatoms were the most abundant MICRO in Mala Solina in January (70\%) and in Velika Solina from November to January (81-91\%). The percentage of coccolithophorids (PRYM) in the MICRO fraction (Fig. 6) was less than $1 \%$ throughout the year, except in Mala Solina in December (44\%). Green algae were found only in Mala Solina from July to September and 

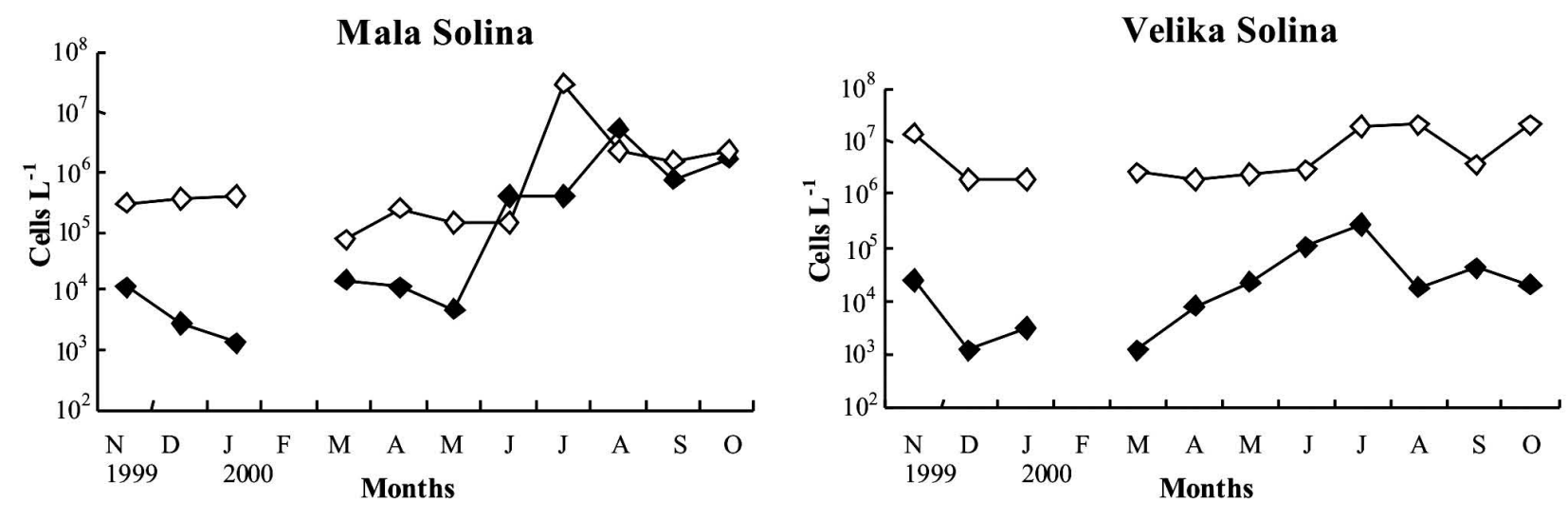

FIG. 5. - Monthly distribution of microphytoplakton (MICRO) and nanophytoplankton (NANO) abundances in Mala Solina and Velika Solina.
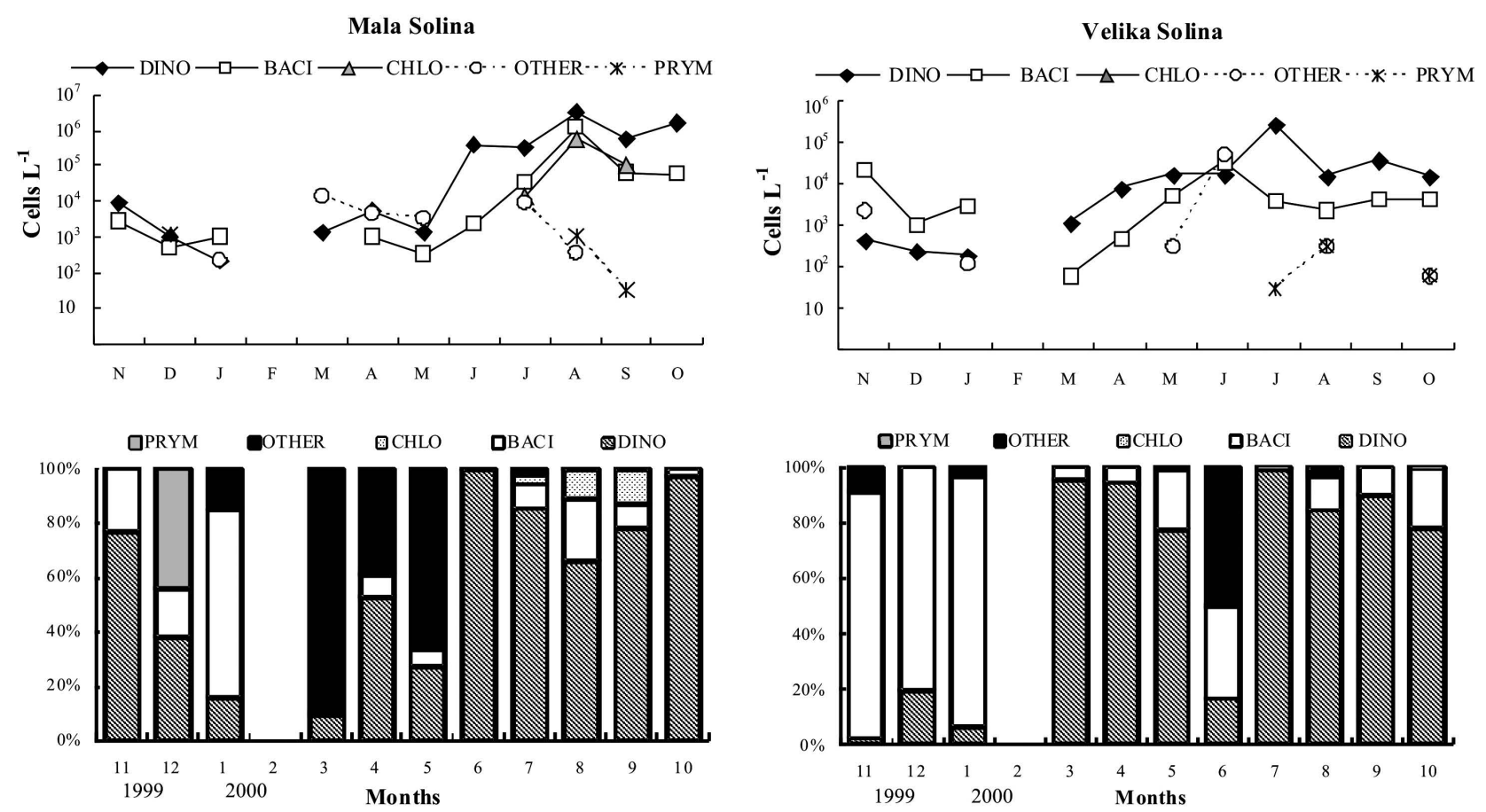

FIG. 6. - Monthly variations and relative contribution of different taxonomic groups to microphytoplankton abundance. DINO, Dinophyceae; BACI, Bacillariophyceae; CHLO, Micromonadophyceae; OTHER, Cyanophyceae and unidentified spherical cells; PRYM, Prymnesiophyceae.

ranged from $1.4 \times 10^{4}$ to $5.89 \times 10^{5}$ cells $\mathrm{L}^{-1}$. The group designated OTHER contained mainly unidentified spherical cells of 20-30 $\mu \mathrm{m}$ (39-90\%) in Mala Solina from March to May and filamentous cyanobacteria $(50 \%)$ in Velika Solina in June.

Nanophytoplankton (NANO) abundances varied over almost three orders of magnitude, from $7.0 \times 10^{4}$ to $3.0 \times 10^{7}$ cells $\mathrm{L}^{-1}$, in Mala Solina and over a much smaller range, from $1.8 \times 10^{6}$ to $2.2 \times 10^{7}$ cells $\mathrm{L}^{-1}$, in Velika Solina (Fig. 5). The highest abundances were in July and August in Mala and Velika Solina, respectively; the lowest occurred in March in Mala Solina and in January in Velika Solina. Chroococoid cyanobacteria dominated NANO in Mala Solina in July $\left(98 \%, 2.9 \times 10^{7}\right.$ cells $\left.\mathrm{L}^{-1}\right)$ but were not found in Velika Solina. NANO cells smaller than $10 \mu \mathrm{m}$ prevailed in both lakes during the rest of the year.

Altogether, 65 taxa (38 genera) of MICRO were identified (Table 1). Most of them were true planktonic (37 taxa or $57 \%$ ). The vast majority of MICRO were either diatoms (34 taxa) or dinoflagellates (26 taxa). Mala Solina had 31 MICRO taxa and Velika Solina had 50. MDS analyses identified two phytoplankton communities: euhaline-mesotrophic and hyperhaline-eutrophic (Fig. 7). According to SIMPER analysis, Oxyrrhis marina $(48.45 \%)$, chroccocoid cyanobacteria $(27.48 \%)$, and Prorocentrum scutellum (8.36\%) contributed most to variance between groups in Mala Solina, whereas 
TABLE 1. - List of microphytoplankton taxa and monthly distribution of their abundance in Mala Solina (M) and Velika Solina (V) during the one-year investigation. Abundances are presented as follows: $1=10-10^{2} ; 2=10^{2}-10^{3} ; 3=10^{3}-10^{4} ; 4=10^{4}-10^{5} ; 5=10^{5}-10^{6} ; 6=10^{6}-10^{7}$ cells $\mathrm{L}^{-1}$.

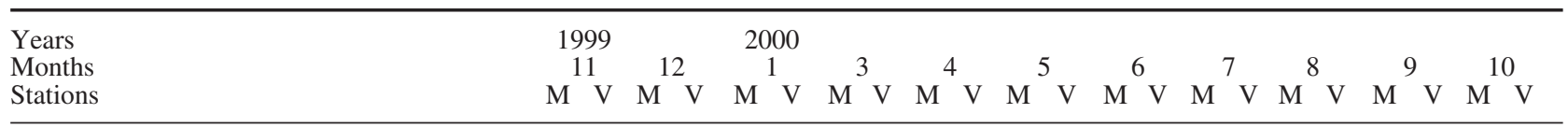

Chlorophyta, Prasinophyceae

Tetraselmis sp.

Primnesiophyta, Primnesiophyceae

Calyptrosphaera oblonga Lohmann

Michaelsarsia adriaticus

(Schiller)Manton, Bremer et Oates

Unidentified coccolithophoridae $>20 \mu \mathrm{m}$

Heterokontophyta, Bacillariophyceae

Amphora ostrearia Brébisson

Amphora sp.

Campylodiscus sp.

Chaetoceros compressus Lauder

Chaetoceros tortissimus Gran

Chaetoceros sp.

Coscinodiscus $\mathrm{sp}$

Cyclotella sp.

Dactyliosolen blavyanus (Peragallo) Hasle

Diploneis bombus (Ehrenberg) Cleve

Diploneis sp.

Eunotia sp.

Gyrosigma sp.

Licmophora flabellata C.Agardh

Lyrella lyra (Ehrenberg) Karajeva

Lyrella sp.

Mastogloia angulata Lewis

Navicula sp.

Naviculoid cells

Nitzschia incerta (Grunow)M.Peragallo

Nitzschia longissima (Brébisson) Ralfs

Nitzschia sp.

Pleurosigma angulatum (Quekett) W.Smith

Pleurosigma elongatum W.Smith

Pleurosigma formosum W.Smith

Pleurosigma sp.

Pseudo-nitzschia spp.

Rhabdonema sp.

Rhizosolenia sp.

Surirella fastuosa Ehrenberg

Synedra fulgens (Greville) W.Smith

Synedra sp.

Thalassionema nitzschioides

(Grunow)Mereschkowsky

Tropidoneis sp.

Ulnaria acus (Kützing)M.Aboal

Unidentified diatoms

Dinophyta, Dinophyceae

Diplopsalis complex

Gonyaulax digitale (Pouchet) Kofoid

Gonyaulax hyalina Ostenfeld et Schmidt

Gonyaulax sp.

Gymnodinium simplex (Lohmann) Kofoid et Swezy.

Gymnodinium sanguineum K.Hirasaka

Gymnodinium spp.

Gymnodinioid cells

Gyrodinium spp.

Neoceratium fusus (Ehrenberg)

F.Gomez, D.Moreira et P.Lopez-Garcia

Oxyrrhis marina Dujardin

Oxytoxum sphaeroideum Stein

Prorocentrum compressum (Bailey) Abé ex Dodge

Prorocentrum maculosumM.A.Faust

Prorocentrum micans Ehrenberg

Prorocentrum minimum (Pavillard) Schiller

Prorocentrum scutellum Schröder

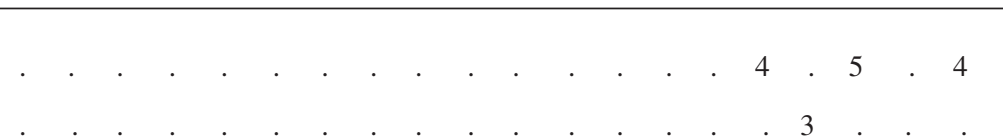

Prorocentrum triestinum Schiller

Prorocentrum sp.

Protoperidinium brochii (Kofoid et Swezy) Balech . 
TABLE 1 (cont.). - List of microphytoplankton taxa and monthly distribution of their abundance in Mala Solina (M) and Velika Solina (V) during the one-year investigation. Abundances are presented as follows: $1=10-10^{2} ; 2=10^{2}-10^{3} ; 3=10^{3}-10^{4} ; 4=10^{4}-10^{5} ; 5=10^{5}-10^{6} ; 6=$ $10^{6}-10^{7}$ cells L ${ }^{-1}$.

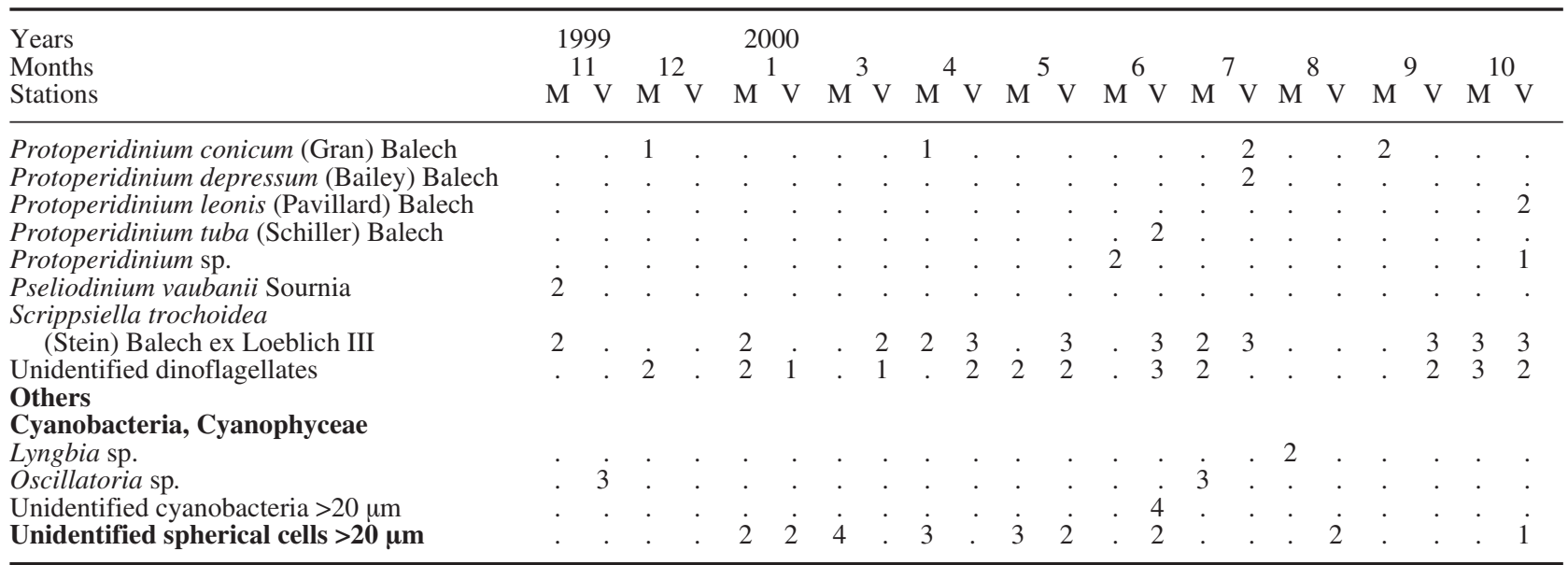

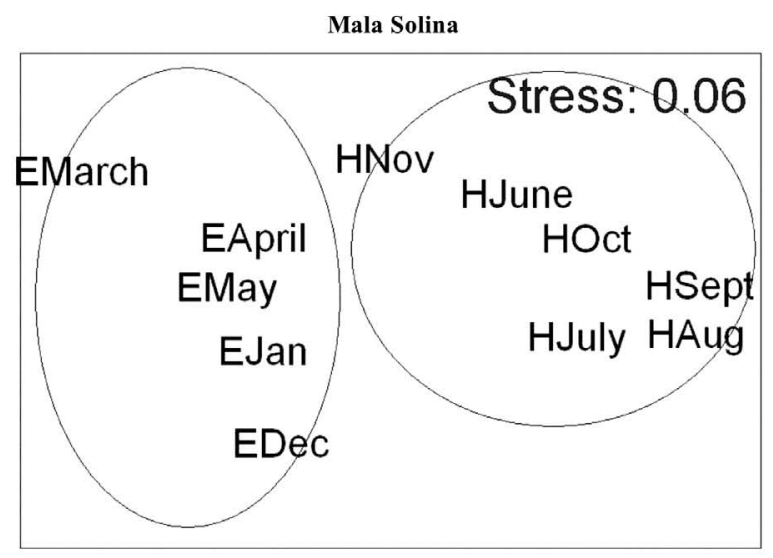

Velika Solina

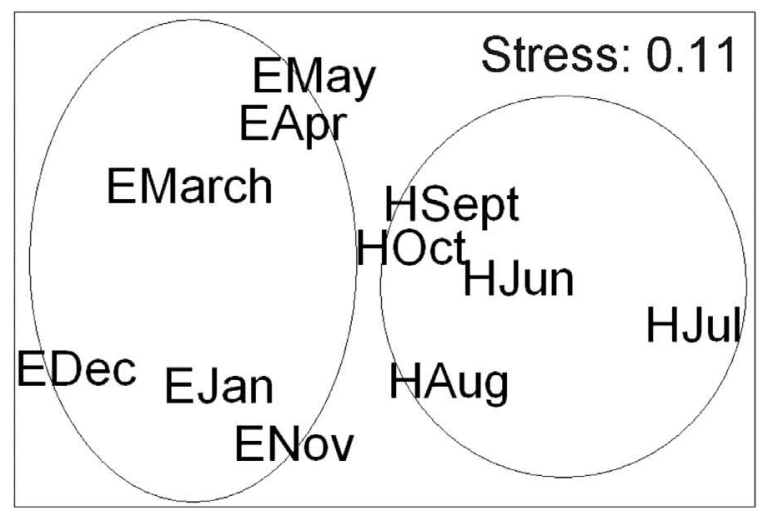

FIG. 7. - MDS ordination of phytoplankton composition and abundance based on the Bray-Curtis similarity matrix in Mala Solina ( stress value $=0.06$, ANOSIM, $\mathrm{p}<0.01$ ) and Velika Solina (stress value $=0.11$, ANOSIM, $\mathrm{p}<0.05$ ). Symbols $\mathrm{E}$ (euhaline) and $\mathrm{H}$ (hyperhaline) refer to the two groups of significantly different phytoplankton communities.

Oxyrrhis marina (40.55\%), Prorocentrum scutellum (24.13\%), and Scrippsiella trochoidea (10.18\%) contributed most to variance in Velika Solina. The most abun-

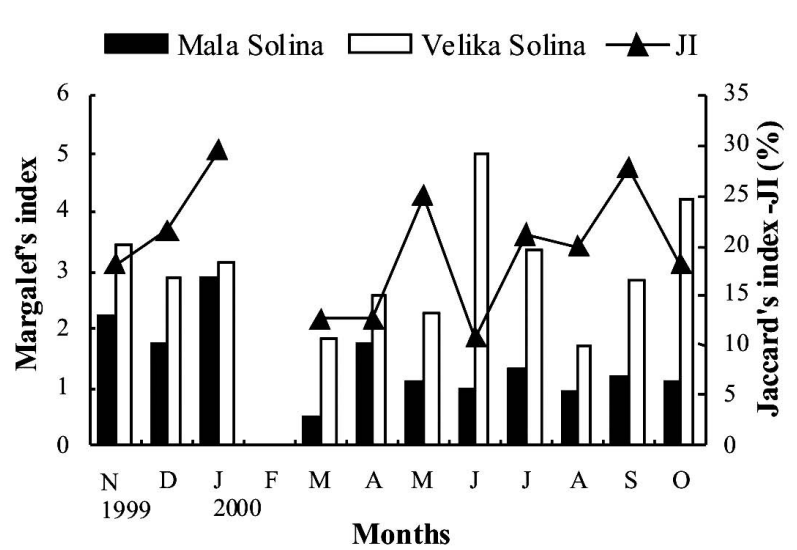

FIG. 8. - Margalef's species richness index in Mala Solina and Velika Solina, and Jaccard's similarity index between the lakes' microphytoplankton.

dant MICRO species in both lakes was Oxyrrhis marina (Table 1). Intense development of this species was found in August in both Mala $\left(3.2 \times 10^{6}\right.$ cells $\left.\mathrm{L}^{-1}\right)$ and Velika Solina $\left(2.5 \times 10^{5}\right.$ cells $\left.\mathrm{L}^{-1}\right)$, and in October $\left(1.6 \times 10^{6}\right.$ cells $\left.\mathrm{L}^{-1}\right)$ only in Mala Solina. Nitzschia longissima and Gonyaulax hyalina also attained high abundance $\left(10^{5}\right.$ to $10^{6}$ cells $\mathrm{L}^{-1}$ ) in Mala Solina in August. The following taxa exceeded $10^{3}$ cells $\mathrm{L}^{-1}$ in Mala Solina: Amphora sp., Gonyaulax sp., Prorocentrum scutellum, Prorocentrum triestinum, Tetraselmis sp., and Scrippsiella trochoidea. MICRO taxa in Velika Solina at more than $10^{3}$ cells $\mathrm{L}^{-1}$ were Chaetoceros tortissimus, Cyclotella sp., Navicula sp., Pseudo-nitzschia spp., Synedra sp., small naviculoid cells, Prorocentrum scutellum, and Scrippsiella trochoidea. Oxyrrhis marina, Tetraselmis sp., and Nitzschia longissima were positively correlated with salinity $(\mathrm{P}<0.05), \mathrm{NH}_{4}(\mathrm{P}<0.001)$, and $\mathrm{PO}_{4}(\mathrm{P}<0.001)$. Amphora sp., Navicula sp., Synedra sp., and small naviculoid cells were positively correlated with $\mathrm{PO}_{4}(\mathrm{P}<0.01)$. No other correlations between phytoplankton taxa and environmental variables were statistically significant. 
MICRO species similarity between lakes was relatively low. Jaccard's index (Fig. 8) varied from 10.7\% to $29.4 \%$, with the highest in January and the lowest in June. Margalef's species richness index (Fig. 8) varied from 0.47 to 2.87 in Mala and from 2.27 to 5.37 in Velika Solina. The highest value in Mala Solina was in January and that in Velika Solina was in June. Species richness generally was higher in Velika Solina throughout the year.

\section{DISCUSSION}

Despite the monthly sampling design, this study provides the first information on phytoplankton structure in hyperhaline marine lakes on the eastern Adriatic coast. The annual cycle of phytoplankton in Mala Solina and Velika Solina during this study was characterized by two periods: a euhaline and mesotrophic period lasting from December to May; and a hyperhaline and eutrophic period lasting from June to November. According to the annual distribution of microphytoplankton abundance, both lakes are moderately eutrophic (Viličić, 1989). During their euhaline period, the lakes do not differ substantially in their hydrographic and chemical characteristics from other euhaline marine lakes along the Croatian coast (Carić and Jasprica, 1998; Ciglenečki et al., 2005; Čalić et al., 2007). During the hyperhaline period, however, in addition to elevated salinity, the lakes also have significantly higher temperatures, oxygen saturations and concentrations of $\mathrm{SiO}_{4}$ and $\mathrm{NH}_{4}$, but lower $\mathrm{NO}_{3}$ and $\mathrm{PO}_{4}$ than coastal lakes of a similar trophic status (Morais et al., 2003).

Seasonal temperature variations in the lakes are typical for the Mediterranean (Blondel and Aronson, 1999; Cushman-Roisin et al., 2007). The summer salinity increase results from the combination of high temperature, low precipitation, and the lakes' high surface-to-volume ratios (3 in Mala Solina and 1.5 in Velika Solina). Temperatures in 2000, in fact, were much higher than the 3-decade (1961-1990) average (Nikolić, 2000). According to Bonacci (1996), potential evaporation in this region is $1200-1300 \mathrm{~mm}$ per year, with the maximum in the order of $200 \mathrm{~mm}$ per month in July and August.

There was an annual peak of MICRO and NANO fractions in each lake. Mala Solina had a higher NANO peak (1.7 times higher than that in Velika Solina) and a much higher MICRO peak (19.3 times higher). These peaks occurred in summer, when temperature and salinity were high, silicate and phosphate reached their annual maxima, and ammonium was slightly elevated. Both $\mathrm{PO}_{4}$ and $\mathrm{NH}_{4}$ were higher in Mala Solina. One phytoplankton peak was also found in some slightly polluted Greek hyperhaline (41-60) lagoons in late winter/early spring (Nicolaidou et al., 2005). In contrast, other parts of the coastal Adriatic have been shown to experience not one but two annual MICRO peaks, most often between March and September (Jasprica and Carić, 1997; Carić and Jasprica, 2005). Some areas of the Mediterranean even have four peaks: one such area is the eutrophic Bay of Iskenderun (Polat $e t$ al., 2000), where the two strongest peaks (August and October) occur when temperature $\left(29.06^{\circ} \mathrm{C}\right)$ and salinity (39.24) are highest. Differences in phytoplankton annual peaks can be explained by environmental conditions, especially salinity and nutrient concentrations in particular ecosystems.

Diatoms and dinoflagellates were the major MICRO components. The diatom maximum was in August but-especially in Velika Solina-diatoms dominated from November to January, a period during which temperature and salinity were low but $\mathrm{NO}_{3}$ and especially $\mathrm{NH}_{4}$ were high. Silicate varied between 2 and $26 \mu \mathrm{M}$ from November to January. This is above the half-saturation constant typical for coastal diatoms (Fisher et $a l ., 1988)$. Diatoms thus should not have been silicatelimited during that period (Carlsson and Granéli, 1999; Granéli et al., 1999). Diatoms commonly enjoy an advantage when $\mathrm{NO}_{3}$ is high (Bode and Dorch, 1996), as is generally the case in the coastal southern Adriatic (Jasprica and Carić, 2001). In a restricted Tunisian lagoon (salinity 32-40) diatoms dominated in spring and summer and also whenever nitrate was high (Sakka Hlaili et al., 2007). Decline of the Si:N ratio from January to March (Fig. 3), with available concentrations of $\mathrm{SiO}_{4}$ falling below the level of reported half-saturation constants (Rocha et al., 2002 and references therein), may have been responsible for limiting diatoms and encouraging the shift to non-siliceous flagellates.

Anthropogenic effects are probably responsible for the higher $\mathrm{PO}_{4}$ levels from June to September and the elevated $\mathrm{NH}_{4}$ concentration of August. This periodthe tourist season-is accompanied by a marked increase in waste discharge. Higher temperatures during this period can also be expected to increase the remineralization rate of organic nitrogen and phosphate in sediments, followed by the release of $\mathrm{NH}_{4}$ and $\mathrm{PO}_{4}$ into the overlying water column. The concentration of $\mathrm{SiO}_{4}$ increased with the onset of higher temperatures and salinities in May and reached its annual maximum in August. The observed peak may result from more rapid regeneration under these warm conditions (Yamada and D'Elia, 1984). Maximum diatom abundance was related to peak silicate; both diatoms and silicate subsequently declined in September and October. The influence of the adjacent coastal water was high in October, as attested by the similarity of nutrient concentrations in both the sea and lakes at that time. $\mathrm{NO}_{3}, \mathrm{SiO}_{4}$, and $\mathrm{PO}_{4}$ in the sea were, respectively, 15, 18, and $0.01 \mu \mathrm{M}$ (Olujić, 2007).

The highest contribution of dinoflagellates to MICRO was mostly from June to October in Mala Solina, and from March to October in Velika Solina. Their dominance coincided with higher temperature, salinity, $\mathrm{PO}_{4}$ and $\mathrm{SiO}_{4}$, but lower $\mathrm{NO}_{3}$. Nitrate was markedly below the half-saturation constant concentration typical of coastal phytoplankton (Fisher et al., 1988; Sommer, 1994). Nitrogen appeared to be limiting from 
May to September (Fig. 3), which is consistent with the findings of Sakka Hlaili et al. (2006) that document the greatest increase in dinoflagellates under $\mathrm{PO}_{4}$ enrichment. $\mathrm{PO}_{4}$ decreased after the dinoflagellate maximum and was most likely limiting from October to December. Abid et al. (2008) found that growing dinoflagellates reduced phosphate concentrations. The alternating dominance of diatoms and dinoflagellates is consistent with the general theme of Margalef's mandala (Margalef, 1983). A transition from diatom to dinoflagellate dominance coincided with a shift from $\mathrm{P}$ - to Si-limitation in both lakes, which agrees with the results of Escaravage et al. (1996).

Filamentous cyanobacteria were found only in Velika Solina (June), where they made up 50\% of MICRO. This is probably a result of their greater temperature tolerance, which exceeds that of most eukaryotic algae (Steiner et al., 1971).

Phytoplankton structure and seasonality were largely similar to those of comparable habitats in the Mediterranean (Abid et al., 2008; Ayadi et al., 2004; Sakka Hlaili and El Grami, 2004; Pavlova et al., 1998). As in the present study, diatoms, dinoflagellates and autotrophic flagellates were the main phytoplankton in these isolated and more-or-less hyperhaline ecosystems. Diatoms developed mostly in autumn-winter and dinoflagellates-especially Oxyrrhis, Scrippsiella, Gonyaulax and Prorocentrum - dominated in summer.

Despite broad similarity in the physical-chemical conditions to which the communities of the two lakes were exposed, each exhibited interesting differences. From the standpoint of structure, the similarity of MICRO species between lakes, as measured by the Jaccard index, was relatively low. Furthermore, Margalef's index was significantly higher in Velika than in Mala Solina. This may be related to Velika Solina's more extensive connection with the sea. Variations in important abiotic parameters not measured in this study (e.g. trace elements and dissolved organic matter), can be expected to affect phytoplankton diversity in these lakes.

The dinoflagellate Oxyrrhis marina was the most abundant MICRO species in this study and was found only during the hyperhaline period (summer-autumn). At the Kalloni saltworks (NE Aegean Sea, Greece) $O x$ yrrhis marina was an abundant species in summer and autumn along the salinity gradient 47-72 (Evagelopoulos et al., 2007, 2009). Additionally, among three ponds of increasing salinity in the Sfax solar saltern (Tunisia), this species was the most abundant in the pond, with a salinity of $78.7 \pm 8.8$ and temperature of $23.7 \pm 7.1$ (Abid et al., 2008). Presence of this widely distributed species (Schiller, 1933; Tomas, 1996), was noted in other hyperhaline environments in the Mediterranean Sea and Black Sea (Ayadi et al., 2004; Pavlova et al., 1998; Quintana and Moreno-Amich, 2002). The higher abundance of O. marina in Mala Solina in comparison with Velika Solina can be explained by the presence of chroococoid cyanobacteria and small MICRO taxa (e.g. green algae and small diatoms). These organisms have been shown to be a major prey type of $O$. marina (Goldman et al., 1989; Hansen, 1991; Schumann et al., 1994). In our study, Tetraselmis sp. was present only in Mala Solina and the high abundance of this taxon may be an important source of prey for $O$. marina. In laboratory conditions, Hansen et al. (1996) reported grazing on Tetraselmis spp. by $O$. marina as they were available at concentrations $\geq 20$ cells mll ${ }^{-1}$ in preference to the smaller algae. Among dinoflagellates, the gymnodinioids, peridinians, and prorocentroids were found in abundance in the lakes. This agrees with the "lifeform" concept of eutrophic coastal waters developed by Smayda and Reynolds (2001), according to which small- to intermediate-sized dinoflagellates predominate relatively shallow, nutrient-enriched, nearshore environments.

The most frequent diatom genera were Amphora sp., Navicula sp., and Navicula-like cells. The most abundant species, Nitzschia longissima, is commonly found in blooms in eastern Adriatic marine lakes (Jasprica and Carić, 2003; Jasprica et al., 2005). Amphora and Navicula include species with very broad ecological tolerance (Raghukumar and Anil, 2003; Patil and Anil, 2005), but their role could not be evaluated properly in the present study because species-level identification was not always possible. The presence of diatoms commonly found in blooms-Chaetoceros, Nitzschia, and Pseudo-nitzschia - suggests the suitability of the highnutrient environment of the lakes for such "eutrophic" species (Totti et al., 2000). Genera common in other Adriatic marine lakes of similar trophic status-Leptocylindrus, Hemiaulus, and Guinardia - were absent in our lakes. This seems to be more related to the stability/ variability pattern than to the trophic status of the shallow ecosystem (Margalef, 1978).

In the present study, the results clearly showed a high contribution of tychoplanktonic taxa from benthos communities (43\%), particularly diatoms. Tychoplanktonic taxa were mainly represented by Amphora, $\mathrm{Na}$ vicula, Niztschia, and naviculoid cells. The same benthic taxa have been found in a shallow Venetian lagoon (Facca and Sfriso, 2007). Schreurs (1992) stressed the features of the lake bottom and the location of the lakes in a windy place as an important factors for appearance of filamentous Cyanophyceae (Oscillatoriales) in the water column. The importance of wind-induced resuspension of bottom sediments on phytoplankton is well recognized in shallow ecosystems (McQuoid and Godhe, 2004; Bonilla et al., 2005), and the shallowness of these lakes certainly makes them susceptible to sediment resuspension. Submerged macrophytes may also have an effect on the phytoplankton taxonomic composition. The leaves of the seagrass (Cymodocea) are an available substratum for numerous epiphytic microalgae ( $c f$. Borowitzka et al., 2006).

Toxic/harmful taxa (e.g. Alexandrium, Dinophysis), expanding in Mediterranean waters, were not recorded in the lakes (Bravo et al., 2008; Ignatiades and Gotsis- 
Skretas, 2010). Among toxic species, Prorocentrum minimum was occasionally presented only in Velika Solina under widely varying salinity and temperatures. According to Heil et al. (2005), this species blooms at high temperatures and low to moderate salinities. In the present study, there were more than one Pseudonitzschia species in the diatom assemblage. Along Pseudo-nitzschia, some other taxa have not been determined at a species level. A detailed taxonomic investigation must be undertaken for a better understanding ecology of the phytoplankton species in the lakes.

The NANO-dominated phytoplankton consisted mostly of phytoflagellates measuring less than $10 \mu \mathrm{m}$, as is generally the case throughout the Adriatic (Saracino and Rubino, 2006). Chroococoid cyanobacteria were the major NANO from May to October, reaching $2.9 \times 10^{7}$ cells $\mathrm{L}^{-1}$ in July, the period of $\mathrm{N}$ limitation. They sometimes dominate throughout the year but they are typically most abundant in summer (Schumann and Karsten, 2006) when they respond to higher temperatures with a growth rate faster than that of either diatoms or green algae (Andersson et al., 1994). The high summer temperatures in the lakes (as high as $27^{\circ} \mathrm{C}$ ) may thus explain this pattern of cyanobacteria dominance. The lakes were eutrophic in summer when temperature and salinity were high and $\mathrm{NO}_{3}$ and the Redfield ratio (DIN/PO $\left.\mathrm{P}_{4}=2-9\right)$ were low. The same conditions were reported for Quinta do Lago, where a long residence time and nitrogen limitation may have favoured the dominance of cyanobacteria (Morais et al., 2003). Cyanobacteria may also bloom in late spring and summer when high water temperatures and low DIN/PO favour their development (Rocha et al., 2002).

Nanophytoplankton and small microphytoplankton (Oxyrrhis, Scrippsiella, and Tetraselmis) with lower half-saturation constants (Eppley et al., 1969) and higher surface-to-volume ratios (Morel et al., 1991) dominated when salinity was high and $\mathrm{N}$ was limiting. Reynolds (2006 and references therein) argues that a high surface-to-volume ratio favours nutrient acquisition and Irwin et al. (2006) predicts an increase in the abundance of larger cells with increasing nutrient availability.

Zooplankton grazing cannot be ignored as a factor in the lakes' phytoplankton patterns. Sakka Hlaili et al. (2007) reported the highest grazing impact on larger algae during the period of diatom abundance, but as zooplankton were not analyzed in this study, this and related topics must remain a subject for future investigation.

In summary, this study adds to the base of information on the structure and function of phytoplankton in two hyperhaline Mediterranean lakes. Of particular note, dense populations of heterotrophic dinoflagellate Oxyrrhis marina and a lack of common coastal diatom species distinguished these systems from those of other marine lakes in the region. The results will prove useful in framing the direction of future research and in establishing the long-term ecological trends of these particular lakes, a subject of increasing importance as the rapid development along the Croatian coast emphasizes the need for rational management of the natural resources, the seasonal tourism industry and the yeararound economies of many coastal communities. For this purpose, a complex ecological investigation was started in January 2010.

\section{ACKNOWLEDGEMENTS}

The authors wish to thank Mate Grgas for his co-operation and assistance in facilitating field sampling. We would like to thank the two anonymous reviewers for their helpful comments. Many thanks also to Nick Staresinic for his comments and help with editing the English. This research was supported by the Ministry of Science, Education and Sports of the Republic of Croatia, under projects 0001001 and 275-0000000-3186.

\section{REFERENCES}

Abid, O., A. Sellami-Kammoun, H. Ayadi, Z. Drira, A. Bouain and L. Aleya. - 2008. Biochemical adaptation of phytoplankton to salinity and nutrient gradients in a coastal solar saltern, Tunisia. Estuar. Coast. Shelf Sci., 80(3): 391-400.

Andersson, A., P. Haecky and A. Hagstrom. - 1994. Effect of temperature and light on the growth of micro-nano- and pico-plankton: impact on algal succession. Mar. Biol., 120(4): 511-520.

Anonymous. - 1959. Final resolution of the symposium on the classification of brackish waters. In: B. Battaglia (ed.), Arch. Oceanogr. Limnol., 11(Suppl.): 243-248.

Ayadi, H., O. Abid, J. Elloumi, A. Bouaïn and T. Sime-Ngando. - 2004. Structure of the phytoplankton communities in two lagoons of different salinity in the Sfax saltern (Tunisia). $J$. Plankton Res., 26(6): 669-679.

Bérard-Therriault, L., M. Poulin and L. Bossé. - 1999. Guide d'identification du phytoplankton marin de l'estuaire et du golfe $d u$ Saint-Laurent. Les presses scientifiques du CNRC, Ottawa.

Blondel, J. and J. Aronson. - 1999. Biology and Wildlife of the Mediterranean Region. Oxford University Press, Oxford-New York.

Bode, A. and Q. Dorch. - 1996. Uptake and regeneration of inorganic nitrogen in coastal waters influenced by the Mississippi River: spatial and seasonal variations. J. Plankton Res., 18(12): 2251-2268.

Bonacci, O. - 1996. Značaj meteoroloških podataka sakupljenih na Palagruži za bilancu voda Jadranskog mora. In: M. Hodžić (ed.), Zbornik radova Simpozija "Palagruža-jadranski dragulj”, pp. 287-291. DHMZ, Split.

Bonilla, S., D. Conde, L. Aubriot, and M. del C. Pérez. - 2005. Influence of Hydrology on Phytoplankton Species Composition and Life Strategies in a Subtropical Coastal Lagoon Periodically Connected with the Atlantic Ocean. Estuaries, 28(6): 884-895.

Borowitzka, M.A., P. Lavery and M. Van Keulen. - 2006. Epiphytes of Seagrasses. In: A. W. D. Larkum, R.J. Orth and C.M. Duarte (eds.), Seagrasses: Biology, Ecology and Conservation, pp. 441-461. Springer, AA Dordrecht.

Bravo, I., M. Vila, M. Masó, R.I. Figueroa and I. Ramilo. - 2008. Alexandrium catenella and Alexandrium minutum blooms in the Mediterranean Sea: Toward the identification of ecological niches. Harmful Algae, 7(4): 515-522.

Brzezinski, M.A. - 1985. The Si:C:N ratio of marine diatoms: interspecific variability and the effect of some environmental variables. J. Phycol., 21(3): 347-357.

Carić, M. and N. Jasprica. - 1998. Seasonal variability of nutrient and chlorophyll $a$ concentrations in the karstic coastal lake Veliko jezero (Mljet island, Adriatic Sea). In: B. Frederic (ed.).

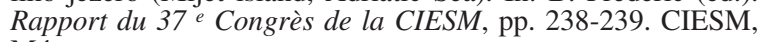
Mónaco. 
Carić, M. and N. Jasprica. - 2005. Resource ratios and phytoplankton in the marine Lake Vlaška (NE Mediterranean). In: E. Ozhan (ed.), Proceeding of the Seventh International Conference on the Mediterranean Coastal Environment, MEDCOAST 05, pp. 541-546. Middle East Technical University, Ankara.

Carlsson, P. and E. Granéli. - 1999. Effects of N:P:Si ratios and zooplankton grazing on phytoplankton communities in the northern Adriatic Sea. II. Phytoplankton species composition. Aquat. Microb. Ecol., 18: 55-65.

Ciglenečki, I., M. Carić, F. Kršinić, D. Viličić and B. Ćosović. -2005 . The extinction by sulfide turnover and recovery of a naturally eutrophic, meromitic seawater lake. J. Mar. Syst., 56: 29-44.

Clarke, K.R. and R.N. Gorley. - 2001. Primer v5: user manual/tutorial. PRIMER-E Ltd, Plymouth.

Clarke, K.R. and R.M. Warwick. - 2001. Change in marine communities: an approach to statistical analysis and interpretation, $2^{\text {nd }}$ edition. PRIMER-E Ltd, Plymouth.

Council Directive 92/43/EEC of 21 May. - 1992. Conservation of natural habitats and of wild fauna and flora. Official Journal L, 206: 07-50.

Cupp, E.E. - 1943. Marine plankton diatoms of the west coast of North America. Bull. Scripps Inst. Oceonog., 5(1):1-238. University of California Press.

Cushman-Roisin, B., K.A. Korotenko, C.E. Galos and D.E. Dietrich. - 2007. Simulation and characterization of the Adriatic Sea mesoscale variability. J. Geophys. Res., 112, C03S14, doi: 10.1029/2006JC003515.

Čalić, M., M. Carić and N. Jasprica. - 2007. Hydrography and planktonic diatoms in the marine lake Mir (eastern Adriatic sea, Croatia). Rapports du $38^{e}$ Congrès de la CIESM, p. 354. CIESM, Mónaco.

Domijan, N. (ed.). - 2006. Izvješće o mareografskim mjerenjima na istočnoj obali Jadrana. Hrvatski hidrografski institut, Split.

Dorth, Q. and T.E. Whitledge. - 1992. Does nitrogen or silicon limit phytoplankton production in the Mississippi River plume and nearby regions? Cont. Shelf Res., 12(11): 1293-1309.

Elloumi, J., J.-F. Carrias, H. Ayadi, T. Sime-Ngando and A. Bouain. - 2009. Communities structure of the planktonic halophiles in the solar saltern of Sfax, Tunisia. Estuar. Coast. Shelf Sci., 81(1): 19-26.

Eppley, R.W., J.N. Rogers and J.J. McCarthy. - 1969. Half-saturation constants for uptake of nitrate and ammonium by marine phytoplankton. Limnol. Oceanogr., 14: 912-920.

Escaravage, V., T.C. Prins, A.C. Smaal and J.C.H. Peeters. - 1996. The response of phytoplankton communities to phosphorus input reduction in mesocosm experiments. J. Exp. Mar. Biol. Ecol., 198(1): 55-79.

Evagelopoulos, A., E. Spyrakos and D. Koutsoubas. - 2007. The biological system of the lower salinity ponds in Kalloni Saltworks (NE. Aegean Sea, Greece): phytoplankton and macrobenthic invertebrates. Transit. Waters Bull., 3: 23-25.

Evagelopoulos, A., E. Spyrakos and D. Koutsoubas. - 2009. Phytoplankton and macrofauna in the low salinity ponds of a productive solar saltworks: spatial variability of community structure and its major abiotic determinants. Global NEST J., 11 (2): 64-72.

Facca, C. and A. Sfriso. - 2007. Epipelic diatom spatial and temporal distribution and relationship with the main environmental parameters in coastal waters. Estuar. Coast. Shelf. Sci., 75: 35-49.

Fisher, T.R., L.W. Harding, D.W. Stanley and L.G. Ward. - 1988. Phytoplankton, nutrients and turbidity in the Chesapeake, Delaware and Hudson estuaries. Estuar. Coast. Shelf Sci., 27(1): 61-93.

Goldman, J.C., M.R. Dennett and H. Gordin. - 1989. Dynamics of herbivorous grazing by the heterotrophic dinoflagellate Oxyrrhis marina. J. Plankton Res., 11: 391-407.

Granéli, E., P. Carlsson, J.T. Turner, P.A. Tester, C. Béchemin, R. Dawson and E. Funari. - 1999. Effects of N:P:Si ratios and zooplankton grazing on phytoplankton communities in the northern Adriatic Sea. I. Nutrients, phytoplankton biomass, and polysaccharide production. Aquat. Microb. Ecol., 18: 37-54.

Hansen, P.J. - 1991. Quantitative importance and trophic role of heterotrophic dinoflagellates in a coastal pelagial food web. Mar. Ecol. Prog. Ser., 73: 253-261.

Hansen, F.C., H.J. Witte and J. Passarge. - 1996. Grazing in the het- erotrophic dinoflagellate Oxyrrhis marina: size selectivity and preference for calcified Emiliania huxleyi cells. Aquat. Microb. Ecol., 10: 307-313.

Heil, C.A., P.M. Glibert and C. Fan. - 2005. Prorocentrum minimum (Pavillard) Schiller - a review of a harmful algal bloom species of growing worldwide importance. Harmful Algae, 4 (3): 449-470.

Holm-Hansen, O., C.J. Lorenzen, R.W. Holmes and J.D.H. Strickland. - 1965. Fluorometric determination of chlorophyll. $J$. Conseil., 301: 3-15.

Horner, R.A. - 2002. A Taxonomic Guide to some Common Marine Phytoplankton. Biopress Ltd., Bristol.

Hustedt, F. - 1930. Die Kieselalgen Deutschlands, Österreichs und der Schweiz mit Berücksichtigung der übrigen Länder Europas sowie der angrenzenden Meeresgebeite. Rabenhorst's Kryptogramen-Flora von Deutschland, Österreich und der Schweiz, Band VII. Akademische Verlagsgesellschaft m. b. H., Leipzig.

Ignatiades, L. and O. Gotsis-Skretas. - 2010. A Review on Toxic and Harmful Algae in Greek Coastal Waters (E. Mediterranean Sea). Toxins, 2: 1019-1037.

Irwin, A.J., Z.V. Finkel, O.M.E. Schofield and P.G. Falkowski. 2006. Scaling-up from nutrient physiology to the size-structure of phytoplankton communities. J. Plankton Res., 28: 459-471.

Jaccard, P. - 1908. Nouvelle recherches sur ladistribution florale. Bull. Soc. Vaud. Sci. Nat., 44: 223-270.

Jasprica, N., D. Viličić, M. Carić and J. Njire. - 1995. Fitoplankton u Malom i Velikom jezeru (otok Mljet, južni Jadran). In: P. Durbešić and A. Benović (eds.), Zbornik radova sa simpozija Prirodne značajke i društvena valorizacija otoka Mljeta, pp. 454-463. Hrvatsko ekološko društvo, Državna uprava za zaštitu kulturne i prirodne baštine, Nacionalni park Mljet.

Jasprica, N. and M. Carić. - 1997. A comparison of phytoplankton biomass estimators and their environmental correlates in the Mali Ston Bay (Southern Adriatic). Mar. Ecol., 18(1): 35-50.

Jasprica, N. and M. Carić. - 2001. Planktonic diatoms and their relation to environmental factors at three stations in the Southern Adriatic, Mediterranean Sea. In: R. Jahn, J.P. Kociolek, A. Witkowski and P. Compère (eds.), Lange-Bertalot-Festschrift: Studies on Diatoms, pp. 517-536. Gantner, Ruggell.

Jasprica N. and M. Carić. - 2003. Mikrofitoplankton u jezeru Vlaška. In: P. Marijanović (ed.), Zbornik radova znanstveno-stru nog simpozija Voda u kršu slivova Cetine, Neretve i Trebišnjice, pp. 575-579. Sveučilište u Mostaru, Bosna i Hercegovina.

Jasprica, N., M. Carić and F. Kršinić. - 2005. Plankton and nutrients in Lake Vlaška (Neretva River estuary, SE Adriatic Sea). In: P. Wassmann and B. Ćosović (eds.), Book of Extended Abstracts of the Symposium "Eutrophication in the coastal zone of the eastern Adriatic Sea", pp. 33-35. Norwegian Research Council, South-eastern Europe Programme Symposium.

Johnson, R.K and T. Wiederholm. - 1992. Pelagic - benthic coupling - the importance of diatom interannual variability for population oscillations of Monoporeia affinis. Limnol. Oceanogr., 37(8): 1596-1607.

Karydis, M. - 2009. Eutrophication assessment of coastal waters based on indicators: a literature review, Global NEST J., 11(4): 373-390.

Kemp, W.M. and W.R. Boynton. - 1984. Spatial and temporal coupling of nutrient inputs to estuarine primary production: the role of particulate transport and decomposition. Bull. Mar. Sci., 35(3): 522-535

Kofoid, C.A. and O. Swezy. - 1921. The free-living unarmored dinoflagellata. University of California Press, Barkley.

Kršinić, F., M. Carić, D. Viličić and I. Ciglenički. - 2000. The calanoid copepod Acartia italica Steuer, phenomenon in the small saline lake Rogoznica (Eastern Adriatic coast). J. Plankton Res., 22(8): 1441-1464.

Lee, R.E. - 1999. Phycology. Cambridge University Press, Cambridge.

Longhurst, A.R. - 1998. Ecological Geography of the Sea. Academic Press, San Diego.

Margalef, R. - 1965. Composición y distribución del fitoplancton. Mem. Fund. La Salle Cienc. Nat., 25: 141-205.

Margalef, R. - 1978. Life-forms as survival alternatives in an unstable environment. Oceanol. Acta, 1: 493-509.

Margalef, R. - 1983. Limnologia. Editorial Omega, Barcelona.

McQuoid, M.R. and A. Godhe. - 2004. Recruitment of coastal planktonic diatoms from benthic versus pelagic cells: Varia- 
tions in bloom development and species composition. Limnol. Oceanogr., 49(4): 1123-1133.

Miller-Way, T. and R.R. Twilley. - 1996. Theory and operation of continuous flow systems for the study of benthic-pelagic coupling. Mar. Ecol. Prog. Ser., 140: 257-269.

Morais, P., M.A. Chícharo and A. Barbosa. - 2003. Phytoplankton dynamics in a coastal saline lake (SE Portugal). Acta Oecol., 24(Suppl.1): 87-96.

Morel, F.M.M., R.J.M. Hudson and N.M. Price. - 1991. Limitation of productivity by trace metals in the sea. Limnol. Oceanogr., 36(8): 1742-1755.

Nikolić, D. - 2000. Bilten iz područja meteorologije, hidrologi$j e$, primjenjene meteorologije $i$ zaštite čovjekova okoliša 1-12/2000. Državni hidrometeorološki zavod, Zagreb.

Nicolaidou, A., S. Reizopoulou, D. Koutsoubas, S. Orfanidis and T. Kevrekidis. - 2005. Biological components of greek lagoonal ecosystems: an overview. Medit. Mar. Sci. 6(2): 31-50.

Olujić, G. - 2007. Comparison of hydrographic properties of the Zrmanja and the Krka estuaries. MSc thesis, University of Zagreb.

Patil, J.S. and A.C. Anil. - 2005. Influence of diatom exopolymers and biofilms on metamorphosis in the barnacle Balanus amphitrite. Mar. Ecol. Prog. Ser., 301: 231-245.

Pavlova, P., K. Markova, S. Tanev and J.S. Davis. - 1998. Observation on a solar saltworks near Burgas, Bulgaria. Int. J. Salt Lake Res., 7(4): 357-368.

Polat, S., E. Sarihan and T. Koray. - 2000. Seasonal changes in the phytoplankton of the northeastern Mediterranean (Bay of Iskenderun). Turk. J. Bot., 24: 1-12.

Quintana, X.D. and R. Moreno-Amich. - 2002. Phytoplankton composition of Empordà salt marshes, Spain and its response to freshwater flux regulation. J. Coast. Res. (spec. issue), 36: 581-590.

Raghukumar, S. and A.C. Anil. - 2003. Marine biodiversity and ecosystem functioning: A perspective. Curr. Sci., 84(7): 884-982.

Redfield, A.C., B.H. Ketchum and A. Richards. - 1963. The influence of organisms on the composition of sea water. In: M. M. Hill (ed.), The sea, vol. 2, pp. 26-77. Interscience, New York.

Reynolds, C.S. - 1997. Vegetation Processes in the Pelagic: A Model for Ecosystem theory. Ecology Institute, Oldendorf/ Luhe, Germany.

Reynolds, C.S. - 2006. The Ecology of Phytoplankton. Cambridge University Press, Cambridge.

Rocha, C. H. Galvão and A. Barbosa - 2002. Role of transient silicon limitation in the development of cyanobacteria blooms in the Guadiana estuary, south-western Iberia. Mar. Ecol. Prog. Ser. 228: 35-45.

Sakka Hlaili, A. and B. El Grami. - 2004. Rôle trophique des protozoaires dans la lagune de Bizerte (Côte Nord de la Tunisie). Rapports du $37^{e}$ Congrès de la CIESM, p. 546. CIESM, Mónaco.

Sakka Hlaili, A., M.-A. Chikhaoui, B. El Grami and H. Hadj Mabrouk. - 2006. Effects of $\mathrm{N}$ and $\mathrm{P}$ supply on phytoplankton in Bizerte Lagoon (western Mediterranean). J. Exp. Mar. Biol. Ecol., 333(1): 79-96.

Sakka Hlaili, A., B. Grami, H. Hadj Mabrouk, M. Gosselin and D. Hamel. - 2007. Phytoplankton growth and microzooplankton grazing rates in a restricted Mediterranean lagoon (Bizerte Lagoon, Tunisia). Mar. Biol., 151(2): 767-783.

Saracino, O.D. and F. Rubino. - 2006. Phytoplankton composition and distribution along the Albanian coast, South Adriatic Sea. Nova Hedwigia, 83(1-2): 253-266.

Schiller, J. - 1933. Dinoflagellatae (Peridineae) in monographischer Behandlung. 1. Teil. Rabenhorst's Krypotgamen-Flora von Deutschland, Österreich un der Schweiz. Akademische Ver- lagsgesellshaft M.B.H., Leipzig

Schiller, J. - 1937. Dinoflagellatae (Peridineae) in monographischer Behandlung. 2. Teil. Rabenhorst's Kryptogamen-Flora von Deutschland, Österreich un der Schweiz. Akademische Verlagsgesellschaft M. B. H., Leipzig.

Schreurs, H. - 1992. Cyanobacterial dominance. Relations to eutrophication and lake morphology. PhD thesis. University of Amsterdam

Schumann, R., B. Munzert, J.-U. Wuensch and H.-P. Spittler. 1994. The feeding biology of Oxyrrhis marina Dujardin (Flagellata). Limnologica, 24(1): 29-34.

Schumann, R. and U. Karsten. - 2006. Phytoplankton im Zingster Strom der Darß-Zingster Boddenkette - 13 Yahre Remesotrophierung. Rostock. Meeresbiol. Beitr., 16: 47-59.

Smayda, T.J. - 1980. Phytoplankton species successions. In: I. Morris (ed.), The Physiological Ecology of Phytoplankton, pp. 493-570. University of California Press, Berkeley.

Smayda, T.J. and C.S. Reynolds. - 2001. Community assembly in marine phytoplankton: application of recent models to harmful dinoflagellate blooms. J. Plankton Res., 23(5): 447-461.

Sommer, U. - 1994. Planktologie. Springer-Verlag, Berlin.

Sournia, A. - 1986. Atlas du phytoplankton marin. Vol. I: Introduction, Cyanophycées, Dictyochophycées, Dinophycées et Raphidophycées. Êditions du CNRS, Paris.

Steiner, R.Y., R. Kunisawa, M. Mandel and G. Cohen-Bazire. 1971. Purification and properties of unicellular blue-green algae (Order Chroococcales). Bacteriol. Rev., 35(2): 171-205.

Strickland, J.D.H. and T.R. Parsons. - 1972. A practical handbook of seawater analysis. J. Fish. Res. Board. Can., 167: 1-310.

Tomas, C.R. (ed.). - 1993. Marine Phytoplankton: A Guide to Naked Flagellates and Coccolithophorids. Academic Press, London.

Tomas, C.R. (ed.). - 1996. Identifying marine diatoms and dinoflagellates. Academic Press, Inc., San Diego.

Totti, C., G. Civitarese, F. Acri, D. Barletta, G. Candelari, E. Paschini and A. Solazzi. - 2000. Seasonal variability of phytoplankton populations in the middle Adriatic sub-basin. J. Plankton Res., 22(9): 1735-1756.

UNESCO. - 1973. International oceanographic tables, Volume 2. National Institute of Oceanography of Great Britain and UNESCO, Paris.

Utermöhl, H. - 1958. Zur Vervollkommnung der quantitativen Phytoplankton-Metodik. Mitt. Int. Ver. Theor. Angew. Limnol., 9: 1-38.

Viličić, D. - 1989. Phytoplankton population density and volume as indicators of eutrophication in the eastern part of the Adriatic Sea. Hydrobiologia, 174:117-132.

Vollenweider, R.A., F. Giovanardi, G. Montanari and A. Rinaldi. - 1998. Characterization of the trophic conditions of marine coastal waters with special reference to the NW Adriatic Sea: proposal for a trophic scale, turbidity and generalized water quality index. Environmetrics, 9: 329-357.

Weiss, R.F. - 1970. The solubility of nitrogen, oxygen and argon in water and seawater. Deep Sea Res., 17: 721-735.

Yamada, S.S. and C.F. D'Elia. - 1984. Silicic-Acid Regeneration from Estuarine Sediment Cores. Mar. Ecol. Prog. Ser., 18: 113-118.

Yin, K., P.Y. Quian, M.C.S. Wu, J.C. Chen, L.M. Huang, X. Song and W.J. Jian. - 2001. Shift from P to N limitation of phytoplankton biomass across the Pearl River estuarine plume during summer. Mar. Ecol. Prog. Ser., 221: 17-28.

Scient. ed.: S. Kuwata.

Received April 13, 2010. Accepted January 13, 2011.

Published online April 27, 2011. 